\title{
Atypical Cerebellar Medulloblastoma Originating from Tentorium: Case Report
}

\author{
Seong-Ho Kim, Chang-Hwan Kim, Oh-Lyong Kim, Chul-Hoon Chang, \\ Sang-Woo Kim, Byung-Yon Choi, Soo-Ho Cho, Jeong-Ok Hah* \\ Department of Neurosurgery and *Department of Pediatrics, \\ College of Medicine. Yeungnam University, Daegu, Korea
}

\begin{abstract}
- Abstract -
The extraaxial presentation of a medulloblastoma is rare. This article describes the case of a 12-year-old boy who presented with severe headache, nausea, and vomiting. The tumor developed in the left tentorium; it was misdiagnosed as a meningioma based on the radiology examination. We review the literature and discuss the atypical presentation of medulloblastoma.
\end{abstract}

Key Words: Atypical medulloblastoma, Tentorium

\section{Introduction}

Medulloblastoma is the most common childhood intracranial tumor, accounting for $25 \%$ of all pediatric intracranial tumors and $33 \%$ of all posterior fossa neoplasms in children. ${ }^{7)}$ The common radiological findings of a medulloblastoma are a hyperdense, well enhancing, well-demarcated mass that develops from the cerebellar vermis; variations are not common. There have been reports of cystic changes, calcifications, and metastasis.' Here we report a case of medulloblastoma, which appeared to be an extraaxial tumor on radiological imaging.

\section{Case report}

A 12-year-old boy, with a headache, nausea, and vomiting presented for evaluation. These symptoms had worsened during the preceding 5 days. The magnetic resonance imaging studies presented a well enhanced and welldemarcated cerebellar mass and central necrosis or cystic changes (Fig. 1). Surgery was performed by the left suboccipital

책임저자 : 김성호, 대구광역시 남구 대명5동 317-1, 영남대학교 의과대학 신경외과학교실

Tel: (053) 620-3790, Fax: (053) 620-3770, E-mail: shkim@medical.yu.ac.kr 


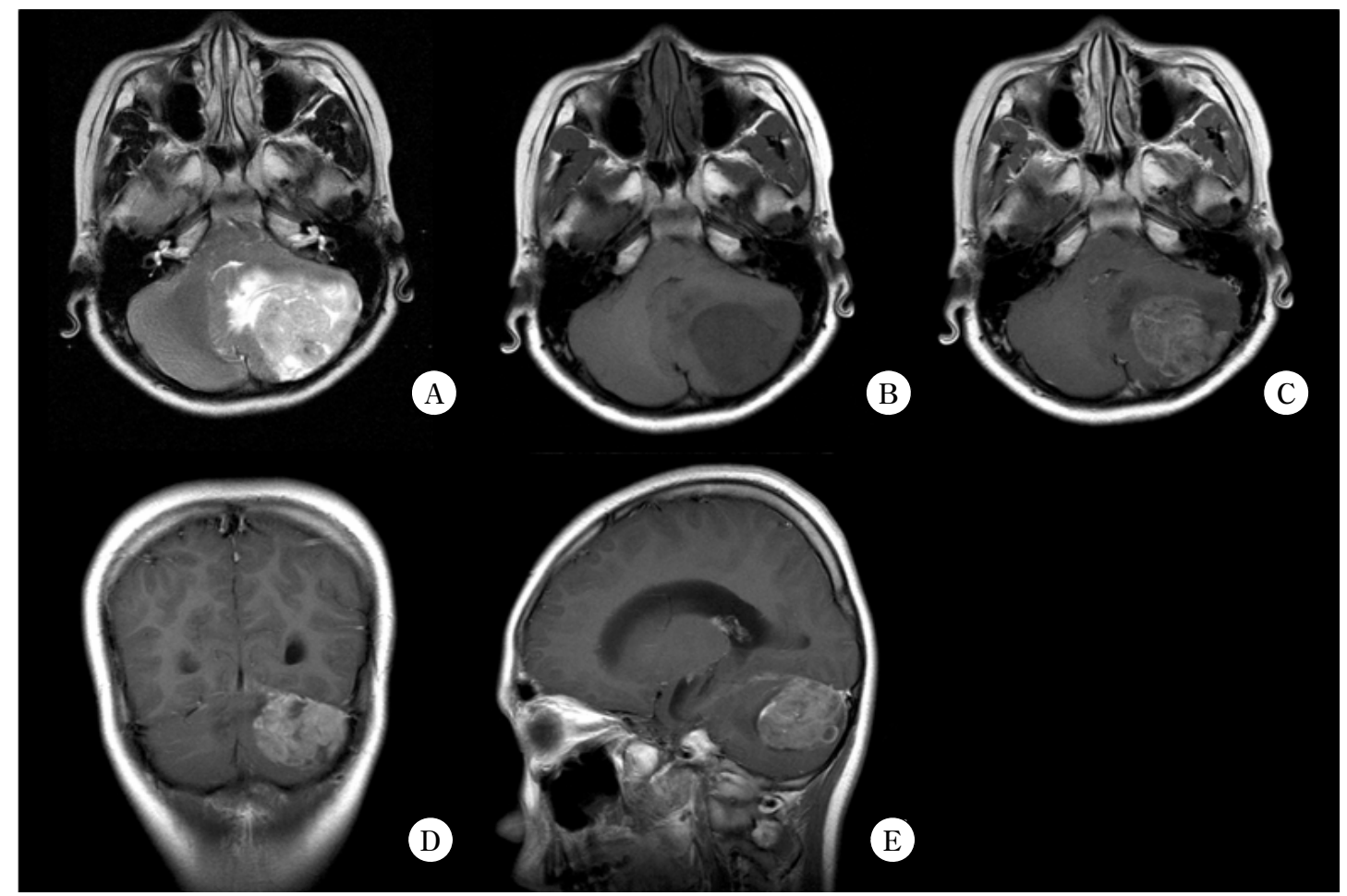

Fig. 1. The mass is shoed high signal intensity on T2-weighted image (1-A), low signal in T1-weighted image (1-B) and strong irregular enhancement accompanying with edema (1-C, D, E). And cystic lesion and calcification is seen in the tumor mass.

approach. The tumor was yellow colored and be totally removed. The histopathology findings had a relatively soft consistency; it adhered were consistent with a medulloblastoma with to the left tentorium. The tumor appeared to neuronal and glial differentiation(Fig. 2). The

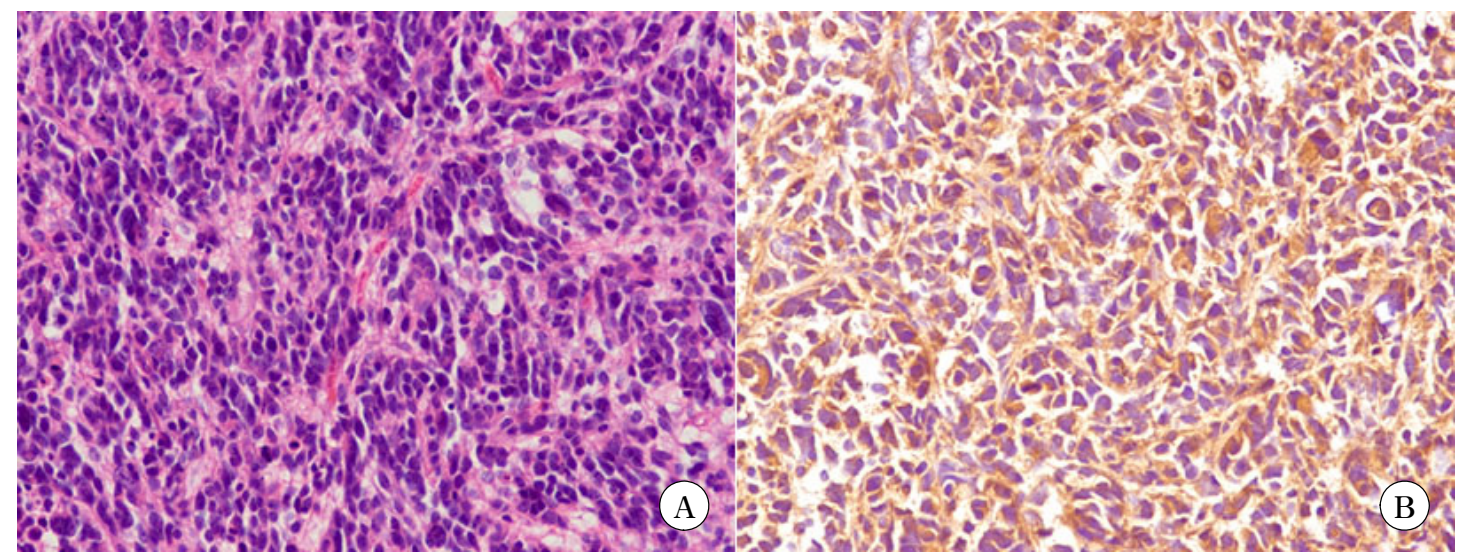

Fig. 2. Microphotograph presents the intensely tumor cells consisting of small oval to carrot-shaped cells with hyperchromatic nuclei (A: H\&E stain X 100, B: Synaptophysin X 200). 
postoperative period was uneventful. The magnetic resonance images (MRI) of the whole spinal cord and the cerebrospinal fluid studies were normal. After we confirmed that there was no residual or metastatic tumor, adjuvant chemotherapy and radiotherapy were administered. After 1 year, follow up of the whole spine by MRI and brain MRI studies were performed, which showed no metastasis or recurrence of tumor.

\section{Discussion}

Most medulloblastomas are located at the midline in the posterior fossa, especially in the cerebellar vermis. The typical imaging findings of cerebellar medulloblastoma are well established. On CT the images appear as a well defined, hyperdense and homogeneous midline mass with marked enhancement after intravenous contrast injection. The typical magnetic resonance images are seen as low signal intensity on T1-weighted images and high signal intensity on T2-weighted images, with marked enhancement after gadolinium injection. In presence of calcification, cystic or necrotic regions, ill-defined margins, and lack of enhancement are atypical features of medulloblastoma during the first decade of life. ') Similar to our case, there is a case report of findings mimicking an extraaxial tumor on radiological examination that originated from the tentorium. ${ }^{2)}$ This was considered in the differential diagnosis as well as other posterior fossa tumors including meningioma, PNET, dysplastic gangliocytoma (LhermitteDuclos disease), and medulloblastoma.

The dural-tail sign can be seen on the T1-weighted magnetic resonance images with enhancement as in this case. Most dural tail signs are associated with meningiomas. However, lesions that are not meningiomas can present with the dural tail sign, such as the glioblastomas multiforme and the acoustic neuroma. ${ }^{3)}$ Detwiler et al. ${ }^{3)}$ reported a medulloblastoma presenting with a dural tail sign. There are many theories on the dural tail sign. Some investigators suggest that this sign reflects tumor extension. Other suggest that it may indicate cortical vein enhancement around the tumor, ${ }^{5)}$ or reactive changes because of hypervascularity and increased loose connective tissue.

Surgery is the most important treatment modality. Postoperative adjuvant therapy is necessary for poor risk groups defined by a young age less than 3 years, residual tumor larger than $1.5 \mathrm{~cm}^{2}$ and metastases. ${ }^{7)}$ Although our patient did not have any of these risk factors, postoperative chemoradiotherapy was performed to improve the patient survival and the disease-free interval. ${ }^{7-9)}$ To date, at the one year follow up there is no recurrence. Recently, postoperative chemotherapy alone is being performed in young children without metastases. ${ }^{10,11)}$ This treatment modality is universally applicable to non-metastatic medulloblastoma. However, there is no coutcome 
- Seong-Ho Kim, Chang-Hwan Kim, Oh-Lyong Kim, Chul-Hoon Chang, Sang-Woo Kim, Byung-Yon Choi, Soo-Ho Cho, Jeong-Ok Hah -

data on chemotherapy alone compared to postoperative chemoradiotherapy. We report an atypical case of cerebellar medulloblastoma originating from the tentorium that was treated with surgical excision and postoperative chemotherapy.

\section{요 약}

수모세포종은 주로 소뇌 충수에서 기원하는 것이 대부분이며, 천막에서 기원하는 경우는 아주 드물다. 본 보고는 심한 두통, 오심, 그리 고 구토 등의 증세로 내원한 12 세 남자 환자의 경우이다. 자기공명영상 검사 상 좌측 천막에 서 기원한 것으로 보이는 종양이 있었으며, 이 를 수막종으로 의심하고 수술적 치료를 시도하 였다. 병리학적 검사 결과는 수모세포종이었다. 이에 본 저자는 천막에서 기원한 비정형적인 수모세포종에 대한 문헌고찰과 저자가 경험한 증례를 보고하고자 한다.

\section{References}

1. Kumar R, Achari G, Banerjee D, Chhabra DK. Uncommon presentation of medulloblastoma. Child's Nerv Syst 2001 Sep;17(9):538-42.

2. Cho JM, Park IS, Kim EY, Ha Y. Medulloblastoma mimicking an extraaxial tumor on radiologic examination. J Korean Neurosurg Soc 2004 Nov;36(5):419-21.

3. Detwiler PW, Henn JS, Porter RW, Lawton MT, White WL, Spetzler RF. Medulloblastoma Presenting with Tentorial "Dural-Tail" Sign: Is The "Dural-Tail" Sign Specific for Meninigioma Skull Base Surg 1998;8(4):233-6.

4. Wilms G, Lammens M, Marchal G, Van
Caleenbergh F, Plets C, Van Fraeyenhoven L, et al. Thickenining of dura surrounding meningiomas: MR features. J Comput Assist Tomogra 1989 Sep-Oct;13(5):763-768.

5. Nagle T, Petersen D, Klose U, Grodd W, Opitz H, Voigt K. The "dural tail" adjacent to meningiomas studied by dynamic contrastenhanced MRI: A comparison with histopathology. Neuroradiology 1994 May;36(4):303-7.

6. Tokumara A, O'uchi T, Eguchi T, Kawamoto S, Kokubo T, Suzuki M, et al. Prominent meningeal enhancement adjacent to meningioma on Gd-DTPA-enhanced MR images: Histopathologic correlation. Radiology 1990 May;175 (2):431-3.

7. Rutkauskiene G, Labanauskea L. Treatment of patients of high-risk group of medulloblastoma with the adjuvant lomustine, cisplatin, and vincristine chemotherapy. Medicine (Kaunas) 2005;41(12):1026-34.

8. Chan AW, Tarbell NJ, Black PM, Louis DN, Frosch MP, Ancukiewicz M, et al. Adult medulloblastoma: Prognostic factors and patterns of relapse. Neurosurgery 2000 Sep;47(3): 623-31.

9. Verlooy J, Mosseri V, Bracard S, Tubiana AL, Kalifa C, Pichon F, et al. Treatment of high risk medulloblastomas in children above the age of 3 years: A SFOP study. European J cancer 2006 Nov;42(17):3004-14.

10. Grill J, Sainte-Rose C, Gentet JC, Lejars O, Frappaz D, Doz F, et al. Treatment of medulloblastoma with postoperative chemotherapy alone: an SFOP prospective trail in young children. Lancet Oncol 2005 Aug;6(8): 573-80.

11. Rutkowski S, Bode U, Deinlein F, Ottensmeier $\mathrm{H}$, Warmuth-Metz M, Soerensen N, et al. Treatment of early childhood medulloblastoma by postoperative chemotherapy alone. N Engl J Med 2005 Mar 10;352(10): 978-86. 